\title{
Efficient Use of Rechargeable Sensor Network's Energ for Transmitting the Data in Optimized Manner
}

\author{
P. Arumugam, T. Krishna Kumar
}

\begin{abstract}
Battery-powered sensor system offers a wide scope of utilizations in territories, for example, traffic observing, restorative consideration, aloof territory, automated investigation, and farming reconnaissance. In RSN, a large number of physically implanted sensor sensors are circulated in perhaps brutal landscape and in many applications; it is difficult to renew vitality by means of supplanting batteries. So consequently energize the batteries from sun powered gadgets. So as to agreeably screen physical or natural conditions, the fundamental undertaking of sensor sensors is to gather and transmit information. It is outstanding that transmitting information expends considerably more vitality than gathering information. The coming of effective revives correspondences and progression in gadgets has empowered the advancement of low-control, ease, and multi-usefulness sensor sensors that are portrayed by scaling down and reconciliation.
\end{abstract}

Index Terms - Information detecting, dynamic topology, vitality portion, vitality reaping, battery-powered sensor systems, steering.

\section{INTRODUCTION}

Remote sensor, everything considered, called wireless sensor and actuator structures (WSAN),spatially appropriated free sensors to screen physical or biological conditions, for instance, temperature, sound, weight, etc and to kindly go their data through the framework to a crucial area. The more present day frameworks are bi-directional, other than spellbinding control of sensor development. The advancement of remote sensor frameworks was affected by military applications, for instance, battle zone observation; today such structures are used in various mechanical and customer applications, for instance, current system watching and control, machine thriving seeing sensor sort center has ordinarily a few parts: a radio handset with an internal amassing contraption or relationship with an outside getting wire, a little scale controller, an electronic circuit for interfacing with the sensors and an essentialness source, for the most part a battery or an embedded kind of giganticness gathering. A sensor center may move in size from that of a shoe box down to the size of a grain of advancement, yet working "bits" of bonafide moment estimations still can't be made.

Revised Manuscript Received on December 11, 2019

P. Arumugam, Research Scholar, Department of CSE, Bharath Institute of Higher Education and Research, Chennai, Tamilnadu, India.

Dr.T. Krishna Kumar, Professor, Department of CSE, Bharath Institute of Higher Education and Research, Chennai, Tamilnadu, India.
* Correspondence Author

\section{EXISITING SYSTEM}

The present framework to locate the base vitality way between a source and a sink to transmit the information. To arranging a to enroll the ideal information distinguishing and controlling strategy change the vitality task will bring enormous correspondence for data trade there is standard issues, in the event of sensor structures, is multi-wrinkle, since it consolidates not just finding the base noteworthiness course from a solitary sensor to objective, yet what's all the more adjusting the course of outstanding centrality of the entire system. The transmitting information expends liberally more importance than get-together information. If there should be an occasion of huge data trade structures are multi-wrinkle. It might cause bunch fiasco.

\section{SYSTEM DESIGN}

The process of design involves conceiving and planning out in mind and making a drawing, pattern or a sketch. The system design transforms a logical representation of what a given system is required to do into the physical reality during development.

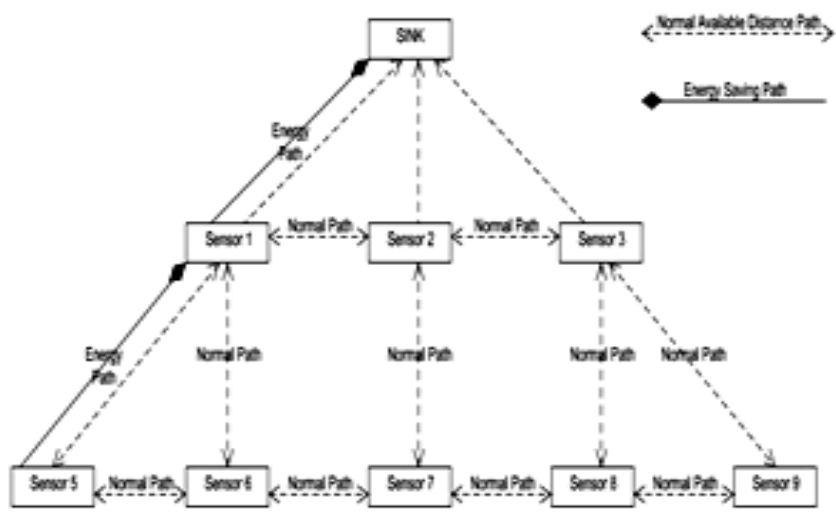

Fig 1. System Archieture

\section{RESULTS}

Network formation:

Each sensor will recognize the temperature and dampness and exhausts imperativeness constantly for at standard interims. Each sensor's imperativeness will be appropriated between Sensing Rate and Transmission subject to the computation. Using multicast connection, all sensors are used to recognize the neighbor sensors. Once in the wake of finding neighbor sensors a line is kept up for each neighboring sensor called as veritable line. 

essentialness will be lessened and it capably adjusts its identifying rate.

\section{A. Distence based route finding:}

Each sensor will distinguish the temperature and sogginess and uses imperativeness continually for at standard interims. Each sensor's imperativeness will be appropriated between Sensing Rate and Transmission subject to the estimation. Using multicast connection, all sensors are used to perceive the neighbor sensors. Once in the wake of finding neighbor sensors a line is kept up for each neighboring sensor called as certifiable line. At the point when the sensor sends the data to the sink, essentialness will be diminished and it dynamically adjusts its identifying rate.

\section{B. Energy based route finding:}

In this vitality based course discovering procedure, each sensor have an individual vitality level .The vitality level is contrast starting with one sensor then onto the next sensor. The most noteworthy vitality level sensor is pick information forwarder. The higher vitality sensors are framing the course for source to sink. In the information transmission process sensors vitality can be decreased relies on the information length. Vitality level will be diminished naturally energize from sun powered cell for every sensor.

\section{Secure data transfer:}

The transmission course is endless supply of data. The data can be disentangled to send through the portrayed course for the ensured transmission. Securely move the data to portrayed way. In the process move sensors are forward the data to sink. The data moving is forward heading in a manner of speaking. The data can be unscrambled to send through the portrayed way.

\section{CONCLUSION}

We structure two calculation BEAS and DSR2C for successfully using the accessible vitality and pick the way to sink that best suits to spare the vitality. To detect the information rates and stream rates, to utilizing deterioration while taking the dynamic of system topology. It relies upon vitality to utilize oversee it appropriate the information, vitality utilization and boosting system lifetime in one dimensional system.

\section{REFERENCES}

1. Kumaravel A., Meetei O.N.,An application of non-uniform cellular automata for efficient cryptography,2013 IEEE Conference on Information and Communication Technologies, ICT 2013,V-,I-,PP-1200-1205,Y-2013

2. Kumarave A., Rangarajan K.,Routing alogrithm over semi-regular tessellations,2013 IEEE Conference on Information and Communication Technologies, ICT 2013,V-,I-,PP-1180-1184,Y-2013

3. Dutta P., Kumaravel A.,A novel approach to trust based identification of leaders in social networks,Indian Journal of Science and Technology,V-9,I-10,PP--,Y-2016

4. Kumaravel A., Dutta P.,Application of Pca for context selection for collaborative filtering,Middle - East Journal of Scientific Research,V-20,I-1,PP-88-93,Y-2014

5. Kumaravel A., Rangarajan K.,Constructing an automaton for exploring dynamic labyrinths,2012 International Conference on Radar,
At the point when the sensor sends the data to the sink,

Communication and

2012,V-,I-,PP-161-165,Y-2012

6. Kumaravel A.,Comparison of two multi-classification approaches for detecting network attacks,World Applied Sciences Journal,V-27,I-11,PP-1461-1465,Y-2013

7. Tariq J., Kumaravel A.,Construction of cellular automata over hexagonal and triangular tessellations for path planning of multi-robots,2016 IEEE International Conference on Computational Intelligence and Computing Research, ICCIC 2016,V-,I-,PP--,Y-2017

8. Sudha M., Kumaravel A.,Analysis and measurement of wave guides using poisson method,Indonesian Journal of Electrical Engineering and Computer Science,V-8,I-2,PP-546-548,Y-2017

9. Ayyappan G., Nalini C., Kumaravel A.,Various approaches of knowledge transfer in academic social network,International Journal of Engineering and Technology,V-,I-,PP-2791-2794,Y-2017

10. Kaliyamurthie, K.P., Sivaraman, K., Ramesh, S. Imposing patient data privacy in wireless medical sensor networks through homomorphic cryptosystems 2016, Journal of Chemical and Pharmaceutical Sciences

11. Kaliyamurthie, K.P., Balasubramanian, P.C. An approach to multi secure to historical malformed documents using integer ripple transfiguration 2016 Journal of Chemical and Pharmaceutical Sciences 9

12. A.Sangeetha,C.Nalini,"Semantic Ranking based on keywords extractions in the web", International Journal of Engineering \& Technology, 7 (2.6) (2018) 290-292

13. S.V.GayathiriDevi,C.Nalini,N.Kumar,"An efficient software verification using multi-layered software verification tool "International Journal of Engineering \& Technology, 7(2.21)2018 454-457

14. C.Nalini,ShwtambariKharabe,"A Comparative Study On Different Techniques Used For Finger - Vein Authentication", International Journal Of Pure And Applied Mathematics, Volume 116 No. 82017 327-333, Issn: 1314-3395

15. M.S. Vivekanandan and Dr. C. Rajabhushanam, "Enabling Privacy Protection and Content Assurance in Geo-Social Networks", International Journal of Innovative Research in Management, Engineering and Technology, Vol 3, Issue 4, pp. 49-55, April 2018.

16. Dr. C. Rajabhushanam, V. Karthik, and G. Vivek, "Elasticity in Cloud Computing", International Journal of Innovative Research in Management, Engineering and Technology, Vol 3, Issue 4, pp. 104-111, April 2018.

17. K. Rangaswamy and Dr. C. Rajabhushanamc, "CCN-Based Congestion Control Mechanism In Dynamic Networks", International Journal of Innovative Research in Management, Engineering and Technology, Vol 3, Issue 4, pp. 117-119, April 2018.

18. Kavitha, R., Nedunchelian, R., "Domain-specific Search engine optimization using healthcare ontology and a neural network backpropagation approach", 2017, Research Journal of Biotechnology, Special Issue 2:157-166

19. Kavitha, G., Kavitha, R., "An analysis to improve throughput of high-power hubs in mobile ad hoc network" , 2016, Journal of Chemical and Pharmaceutical Sciences, Vol-9, Issue-2: 361-363

20. Kavitha, G., Kavitha, R., "Dipping interference to supplement throughput in MANET", 2016, Journal of Chemical and Pharmaceutical Sciences, Vol-9, Issue-2: 357-360

21. Michael, G., Chandrasekar, A.,'Leader election based malicious detection and response system in MANET using mechanism design approach", Journal of Chemical and Pharmaceutical Sciences(JCPS) Volume 9 Issue 2, April - June 2016

22. Michael, G., Chandrasekar, A.,"Modeling of detection of camouflaging worm using epidemic dynamic model and power spectral density", Journal of Chemical and Pharmaceutical Sciences(JCPS) Volume 9 Issue 2, April - June 2016

23. Pothumani, S., Sriram, M., Sridhar, J., Arul Selvan, G., Secure mobile agents communication on intranet,Journal of Chemical and Pharmaceutical Sciences, volume 9, Issue 3, Pg No S32-S35, 2016

24. Pothumani, S., Sriram, M., Sridhar , Various schemes for database encryption-a survey, Journal of Chemical and Pharmaceutical Sciences, volume 9, Issue 3, Pg NoS103-S106, 2016

25. Pothumani, S., Sriram, M., Sridhar, A novel economic framework for cloud and grid computing, Journal of Chemical and Pharmaceutical Sciences, volume 9, Issue 3, Pg No S29-S31, 2016

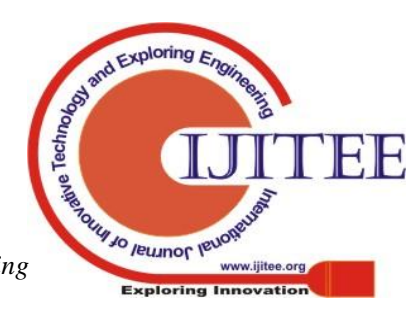


26. Priya, N., Sridhar, J., Sriram, M. "Ecommerce Transaction Security Challenges and Prevention Methods- New Approach" 2016 ,Journal of Chemical and Pharmaceutical Sciences, JCPS Volume 9 Issue 3.page no:S66-S68

27. Priya, N.,Sridhar,J.,Sriram, M."Vehicular cloud computing security issues and solutions" Journal of Chemical and Pharmaceutical Sciences(JCPS) Volume 9 Issue 2, April - June 2016

28. Priya, N., Sridhar, J., Sriram, M. "Mobile large data storage security in cloud computing environment-a new approach" JCPS Volume 9 Issue 2. April - June 2016

29. Anuradha.C, Khanna.V, "Improving network performance and security in WSN using decentralized hypothesis testing "Journal of Chemical and Pharmaceutical Sciences(JCPS) Volume 9 Issue 2, April - June 2016.

\section{AUTHORS PROFILE}

P. Arumugam, Research Scholar, Department of CSE Bharath Institute of Higher Education and Research, Chennai, Tamilnadu, India.

Dr.T. Krishna Kumar, Professor, Department of CSE, Bharath Institute of Higher Education and Research, Chennai, Tamilnadu, India. 